\title{
An Overview of Traditional Small-Scale Poultry Production in Low-Income, Food-Deficit Countries
}

\author{
Wilson RT* \\ Bartridge House, Umberleigh, EX37 9AS, UK \\ *Corresponding author: Wilson RT, Bartridge House, \\ Umberleigh, EX37 9AS, UK
}

Received: March 15, 2021; Accepted: April 07, 2021; Published: April 14, 2021

\begin{abstract}
Poultry production is an activity that is engaged in by a majority of traditional small-scale farmers around the world. The percentage of participants engaged in this enterprise exceeds all those participating in other forms of domestic livestock production. Domestic fowl ("chickens") are overwhelmingly the main species around the globe world but at least eight other species of bird are reared with regional preferences for one or the other type. A multitude of breeds or varieties are present within species which provide a genetic resource of truly inestimable value and whose genes need to be conserved for posterity. Output of live birds, meat and eggs is low in the mainly extensive or semi-intensive production systems but input costs (labour, feed and medicines) are also low. Poultry contribute to poverty alleviation, household food security, create opportunities for employment and are an asset that can be rapidly converted to income. Women and children are often the principal beneficiaries of small-scale production both as managers and owners. Housing is often rudimentary, the mainly scavenged feed is of inadequate quantity and quality and health interventions are minimal except for vaccination against the plagues of Newcastle Disease and Avian Influenza. Marketing of surplus birds or product sales is largely informal but the system is quite appropriate for the sector. Official policies relating to traditional production are often minimal. There are opportunities for improved production and thus for contributing to human welfare in training of owners in management and in improving nutrition and health of the birds.
\end{abstract}

Keywords: Poverty alleviation; Food security; Gender; Nutrition; Genetic resources; Marketing

\section{Introduction}

It has been estimated that in 1961 there were almost 4 billion domestic fowl ("chickens", by far the most numerous of the poultry species) whereas in 2019 there were almost 26 billion, a more that 6 -fold increase in 60 years [1]. Almost half of all poultry reside in Asia, 28 percent in the Americas, 15 percent in Europe and 8 percent in Africa. During the second half of the $20^{\text {th }}$ Century modern and highly intensive poultry production units specialized for either meat or eggs were been established almost everywhere [2]. Quantitative genetics were used to produce hybrids with hen-housed egg averages of up to 95 percent for layers and very rapid weight gains at very efficient feed conversion ratios for broilers. Such intensive production-driven by consumer demand for cheap food-resulted in the virtual disappearance of traditional dual purpose or utility breeds in much of the western world. Some breeds that were common as late as 1960 including the several colour morphs of the Leghorn, the Orpington and Plymouth Rock had almost disappeared 20 years later although the White Leghorn is the base of many of the hybrid layer types. According to one source 74 percent of the world's poultry meat and 68 percent of eggs are now produced intensively [3]. The increase in numbers, especially in "Western" counties has largely been driven by changes in human dietary habits. In the United Kingdom, for example, in 1950 British people ate less than $1 \mathrm{~kg}$ of chicken meat per annum whereas recently consumption has risen to $25 \mathrm{~kg}$ in a year and in the USA 1950 consumption averaged $9 \mathrm{~kg}$ per person whereas in
2017 this had risen to almost $42 \mathrm{~kg}$ [4].

Low-Income, Food-Deficit Countries (LIFDCs) have not been exempt from the process of intensive commercial production. In Sudan, for example, a private (foreign owned) company has recently set up eight operations producing broilers and four the production of table eggs together with modern slaughtering and processing facilities (http://ommat.com/en/companies.html). Private sector commercial poultry production that uses improved genetics, manufactured feeds and formal management, has grown rapidly in Bangladesh over the last 30 years. Bangladesh has six grandparent farms that supply 80 percent of the total demand for parent stock and 82 parent stock farms produce 55 to 60 million day-old broilers (about 40 percent of all meat consumed is from commercial broilers) and 0.5 million day-old layers every week. Between 1995-1996 and 2012-2013 the consumption of chicken meat rose from $3.7 \mathrm{~kg}$ to $16.5 \mathrm{~kg}$ and that of eggs from 21 to 33 per person per year in Bangladesh [5]. Throughout the LIFDCs most industrial units are located near larger population centers so urban dwellers are the main beneficiaries of an increased animal protein supply.

At the very end of the Twentieth Century, however, there was public reaction against "factory" farming, more concern for animal welfare, considerations of food safety and a desire for "wholesome" or organic food. These factors have resulted in a return in many areas, including the developed economies, to traditional more extensive or free range production and the revival or resuscitation 
of some traditional breeds. Thus, in spite of the very rapid growth and enormous scale of industrial commercial poultry production, traditional small-scale production from mainly indigenous stock provides the bulk of poultry output in almost all developing countries [6]. No other domestic livestock type has such universal importance as a source of human food. In Ethiopia some 95 percent of poultry, overwhelmingly domestic fowl, are kept in the village, mainly scavenging, system and only 5 percent are in industrial systems [7]. In the Lao People's Democratic Republic, some 95 percent of the national poultry flock is found in the traditional or smallholder village sector with the remaining 5 percent in the modern or industrial sector [8]. In Zimbabwe the extremely well developed modern layer and poultry industries dominate marketed production but in real terms smallscale production at real values had an output valued at seven times that of the commercial industries [9]. In Senegal in the 1990s some 70 percent of all poultry meat and 12 percent of all meat consumed in the country derived from the traditional poultry industry [10].

In summary, traditional small-scale poultry production is entirely appropriate for supplying the rapidly expanding human population with high-quality food and income to the generally resource-poor small producers. It makes a major contribution to food security, creation of employment, poverty alleviation and the sound ecological management of natural resources [11]. Differences in wealth in the livestock sector are notably divided across gender lines with some 65 per cent of male-headed households participating in livestock activities whereas the statistic for female-headed households is only 51 percent. In small-scale poultry production, however, the role of women and children is much greater than for ruminant stock and thus contributes to parity for these often marginalized groups $[12,13]$.

The species and types of poultry used in the traditional smallscale sector are described in this paper, which also looks at their genetics, examines management, feeding and health practices, discusses marketing channels and comments on the economic and socio-economic functions of the sector.

\section{Methodology}

This paper is based in part on a thorough review of the literature on traditional smallholder poultry production. Several global databases were searched and articles identified in these sources were also used to identify additional relevant sources. The paper is also based in part on the experience of the Author in production, development and research in many countries across several continents during a period of 60 years with a view to improving the welfare of people and livestock alike.

\section{Results}

\section{Production systems}

Intensive production in the less developed countries has not (yet) assumed the same dominant position as in the west. Traditional breeds (or more correctly types) have survived and even thrived and extensive and scavenging systems dominate everywhere except in the vicinity of the major urban centers. Even in these last places, however, urban and periurban production by families who still have close rural ties is an important source of animal protein although here some use may be made of improved breeds or hybrid types [14].
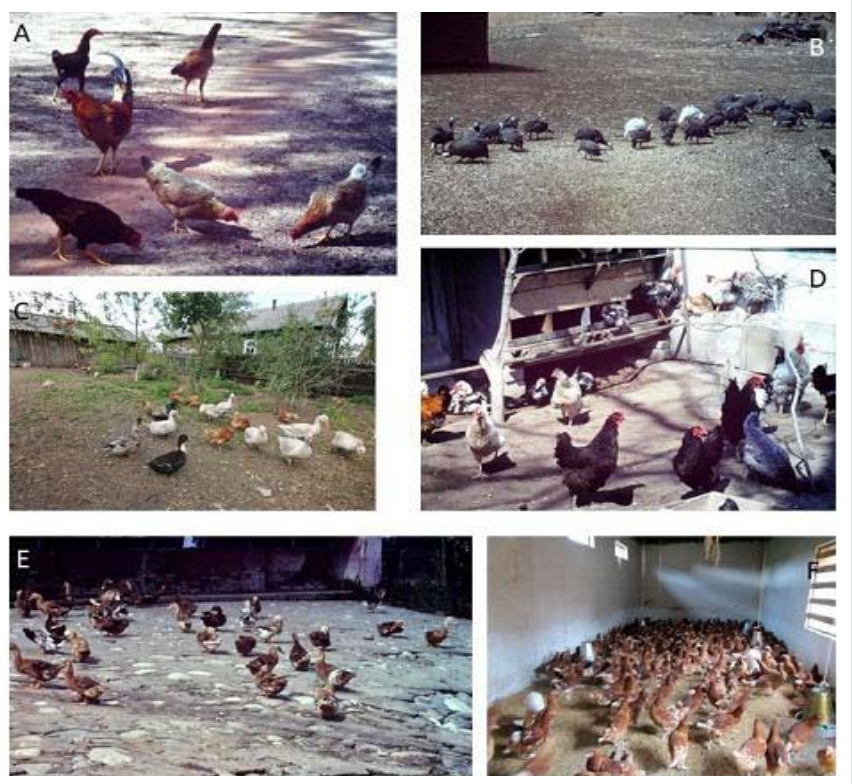

Figure 1: Traditional poultry small-scale production systems: A) Ri type flock scavenging rice near Dong Ho, Vietnam, 26 November 1995; B) Guinea fow scavenging freely at Tamale town, Ghana, 25 March 1993; C) Semi-intensive mixed poultry flock in Kirilov village, Russia, 05 September 2017; D) Private family semi-intensive mixed flock in Bishkek, Kyrgystan, 04 April 1996; E-F) Intensive duck production near Hetauda, Nepal, 25 September 1994 intensive layer production flock in Iringa town, Tanzania, 18 January 2013.

Small-scale poultry production as a term generally refers to domestic fowl ("chickens") [15]. The chicken, certainly, is overwhelmingly dominant in this universe but several other species of bird are kept by smallholders (see next section). Small scale traditional production relies largely on family labour, locally available feed resources including agricultural and household waste, and "native" bird types [16]. Domestic fowl under traditional management in the tropics and subtropics are almost universally referred to by their owners, scientists and development workers as "local" or "native" or by some vernacular term such as 'beledi' (Arabic = country or region), 'kienyeji (Kiswahili $=$ native) or 'desi' Hindi $=$ indigenous) (Author's personal knowledge).

It is possible to distinguish four classes of traditional production (although the one often merges into the other) (Figure 1):

- Small extensive scavenging with 1 to 5 adult birds of different species and ages (in LIFDCs about four-fifths of small producers practice this and the next system in which birds are range freely during the day and scavenge for food over a wide area but return at night to basic shelters birds or roost outside in trees and lay their eggs wherever they find convenient).

- $\quad$ Extensive scavenging with 5 to 50 birds.

- Semi-intensive with 50 to 200 birds (birds are confined to a prescribed area often with some shelter and provided with feed and water in a system that is predominantly urban and peri-urban).

- Small-scale intensive production with more than 200 broilers or more than 100 layers (birds are fully confined either in houses or cages, are totally dependent on their owners for all their requirements including labour, feed and healthcare). 
Table 1: Numbers of poultry species showing relative importance in selected countries and regions/a.

\begin{tabular}{|c|c|c|c|c|c|}
\hline \multirow{2}{*}{ Country and Region } & \multicolumn{5}{|c|}{ Species } \\
\hline & Chicken & Duck & Goose + Guinea Fowl & Turkey & Pigeon \\
\hline Bangladesh, South Asia & $286,903,000$ & $57,119,000$ & & & \\
\hline Cambodia, South East Asia & $13,263,000$ & $9,033,000$ & & & \\
\hline China & $5,146,145,000$ & $712,226,000$ & $310,639,000$ & & \\
\hline Croatia, Eastern Europe & 12,162 & 52,000 & 17,000 & 511,000 & \\
\hline Egypt, North Africa & $169,084,000$ & $5,625,000$ & $7,082,000$ & $3,388,000$ & $5,800,000$ \\
\hline \multicolumn{6}{|l|}{ Ethiopia, Northeast Africa } \\
\hline Gambia, West Africa & $1,476,000$ & & & & \\
\hline Guatemala, Central America & $36,931,000$ & & & & \\
\hline India, South Asia & $807,894,000$ & $33,511,000$ & & & \\
\hline Kyrgyzstan, Central Asia & $4,822,000$ & 88,000 & 42,000 & 188,000 & \\
\hline Lao PDR, South East Asia & $41,394,000$ & $3,600,000$ & 111,000 & & \\
\hline Myanmar, South East Asia & $394,618,000$ & $30,681,000$ & $4,954,000$ & 3,000 & 85,000 \\
\hline Nepal, South Asia & $75,709,000$ & 416,000 & & & \\
\hline Nigeria, West Africa & 167,812 & & & & \\
\hline Peru, South America ${ }^{a}$ & $168,173,000$ & & & & \\
\hline Qatar, Middle East & $9,711,000$ & & & & \\
\hline Russian Federation & $497,395,000$ & $21,149,000$ & $3,574,000$ & $8,669,000$ & \\
\hline Sudan, North Africa & $50,015,000$ & & & & \\
\hline Turkey, Near East & $342,567,000$ & 520,000 & $1,157,000$ & 4,541 & \\
\hline Viet Nam, South East Asia & $382,597,000$ & $82,536,000$ & & & \\
\hline Zimbabwe, Central Africa & $8,749,000$ & 88,000 & & 30,000 & \\
\hline
\end{tabular}

Note: a) it is not possible to disaggregate between intensive commercial and traditional smal; I: scale numbers

Source: Constructed by the Author from data in [1]

\section{Species and breeds}

The domestic fowl dominates general references to the traditional small-scale poultry production sector but many other species of domesticated birds are bred and reared throughout the world. In order of probable importance on a global scale are the domestic fowl (Gallus gallus), Guinea fowl (Numida meleagris), common (Anas platyrhynchos) and Muscovy (Cairina moschata) ducks, common (Anser anser) and Chinese (Anser cygnoides) geese, turkeys (Meleagris gallopavo), pigeons (Columba livea) and Japanese quail (Coturnix japonica) (Figure 2). The overall balance of the national flock is heavily weighted in favour of chickens in Africa and South Asia but ducks are relatively more common in South East and East Asia and South America (Table 1). In a study in Bangladesh all farmers reared native chicken and 54 percent reared ducks: 75 percent reared both chicken and duck together, 17.5 percent reared only chicken and 7.5 percent reared chicken, duck and pigeon at a time. The average populations per household of chicken were 10.4, of duck 9.95 and of pigeon 4.0 [18]. Some attention is given to Guinea fowl and turkeys but pigeons are usually disdained and dismissed as scavengers not needing any feed, considered to be "pets", looked after by children and eaten in some countries only for ritual purposes [19].

Birds of all species reared by small-scale producers are usually referred to as "local" or "native" but most species are not indigenous. It is not known with certainty where chickens were first domesticated but it is almost certain that it was in South or South East Asia although there were probably several distinct geographical areas where the domestic fowl was brought into the human fold. Four wild species of Gallus could be implicated in the origin of the domestic fowl but the Red Jungle Fowl Gallus gallus is the most likely candidate as its crosses on domestic fowl are fully fertile whereas the hybrid offspring of the other three jungle species are not [20]. The Guinea fowl originated from wild birds in West Africa, the common duck in Europe, the Muscovy duck in South America, geese in Asia, turkeys in the Americas, pigeons in Europe and quail (and other "pheasants") in Asia.

There is little formal characterization of small-holder poultry but many "breeds" or distinct types of tropical native fowl are recognized. There are indeed very many in Southeast Asia [21]. The White Chitagong of India and the Canton of Malaysia are examples of local breeds that are relatively good egg layers. In Zimbabwe -- although there has been no formal characterization -- smallholder farmers in communal areas recognize dwarf ('chineya') and barred ('guru re hanga') types [9]. Two distinct colour types recognized in Mali are the 'koko-chié' and 'dakieés-chié' [22]. Colour types, including 'tukur', 'kei', 'gebsima' and netch' are also regarded as "breeds" in Ethiopia [23]. The 'ri' type is well known in Viet Nam and is found in most backyard flocks [24]. All local chickens in Nepal are referred to as Sakini but this is not a uniform breed or type [25]. In Turkey only one indigenous breed of duck and one of goose are recognized by Government but local producers admit to various colour morphs 

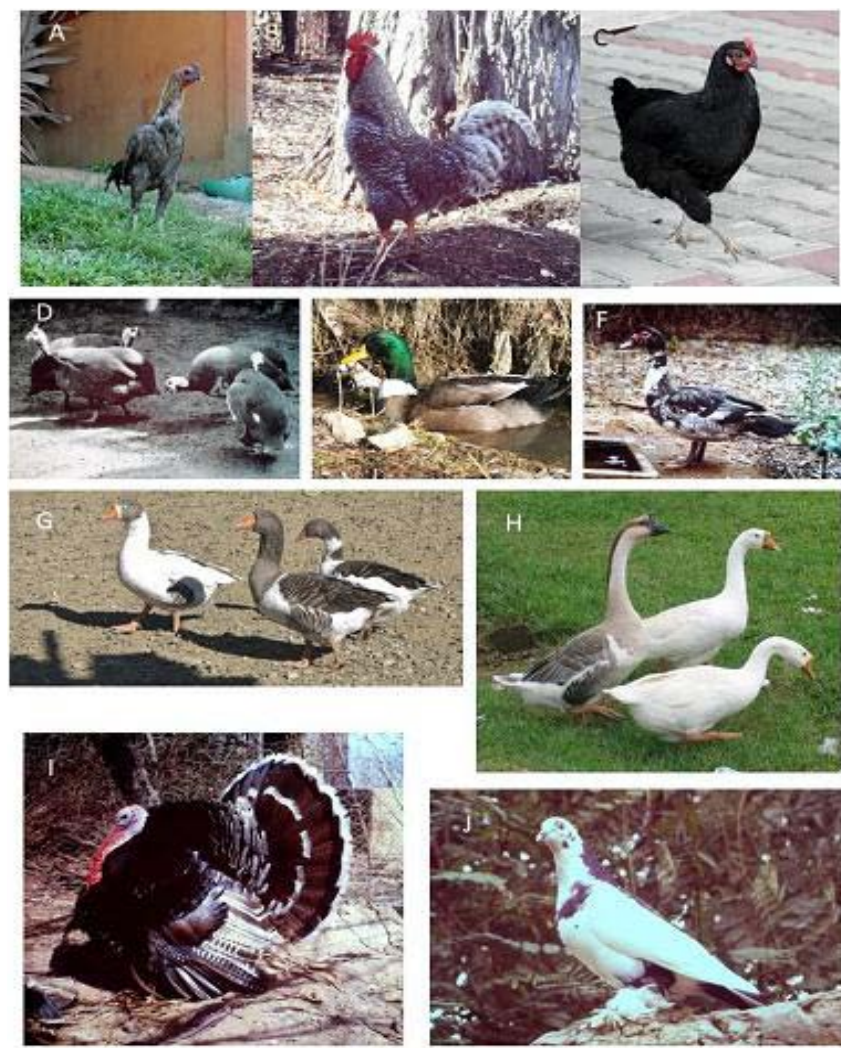

Figure 2: Poultry species used in traditional small-scale poultry production: A) Typical unadulterated "native" chicken, Isle Ste Marie, Madagascar, 27 February 2018; B) Speckled native fowl Issy Kul, Kyrgyzstan, 28 March 1996; C) Improved hen in small-scale system, Asphalt Lake, Trinidad, 7 February 2015; D) Free-ranging Guinea fowl, Southern Region, Mali, 16 January 1993 E) Common duck, Muş Province, Turkey, 16 August 1997; F) Muscovy duck, Kongwa, Tanzania, 2 June 1964; G) Common goose, Lefka, Northern Cyprus 19 November 2015; H) Chinese goose, Khonket, Lao People's Democratic Republic, 25 June 2007; I) Turkey, Kongwa, Tanzania, 1 October 1963; J) Pigeon, Niono, Mali, 10 May 1985.

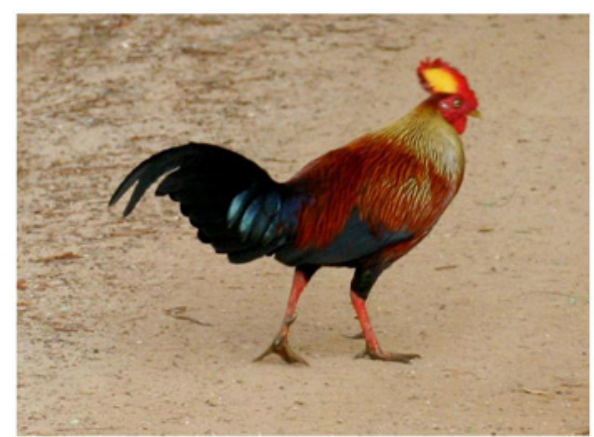

Figure 3: Red Jungle Fowl cock, the progenitor of domestic chickens, Yala National Park, Sri Lanka, 1 March 2012

of both species and are aware that these show differences in growth and egg weights [26]. One source states that Africa has five breeds of pigeon of which three are from Chad, Asia and the Pacific have five breeds, Latin America and the Caribbean islands only one breed and Europe has six breeds with two of these coming from Belgium [19]. Any pigeon breeder in the UK, for example, would consider these numbers as derisory and at least 72 breeds have been identified

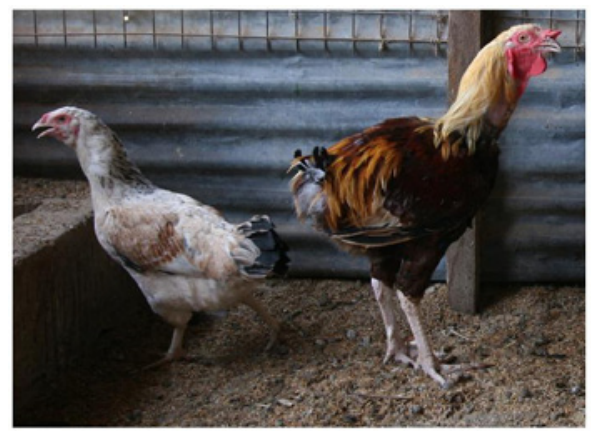

Figure 4: Male 'kuchi' chicken alongside small traditional type, Sokoine University of Agriculture, Tanzania, 28 January 2013.

in Turkey where they are kept for pleasure and for food by many hundreds of "fanciers" [27]. In Egypt (where pigeons are important in sport racing and - as in other Arab countries - for food) mDNA was used to characterize ten well known and clearly identified ten pigeon breeds [28].

A general characteristic of tropical indigenous chickens is their small size with hens usually weighing under $1200 \mathrm{~g}$ and cocks under 1600g. In Sudan [29] and Mali [30] hens weigh about 1000-1100 $\mathrm{g}$ and cocks up to $1600 \mathrm{~g}$. In Sri Lanka average mature hen weight is $1259 \pm$ $209 \mathrm{~g}$ [31]. Feather colouring is very variable inconsistent but is often a shade of brown mixed with red or gold and barring is common. Black is another common colour in tropical birds but white is rare. Several comb types are also seen including single, pea, buttercup and rose. Feathers are usually wiry and may have little down and there are occasionally feathers on the shanks. Exceptions to the general rule of small size are found in areas where fowl have been used in the past for fighting. In India the Aseel is one such variety. These birds typically reach $1800 \mathrm{~g}$ at six months but grow on to $4.5 \mathrm{~kg}$ or even $6.0 \mathrm{~kg}$ at maturity. In India the Aseel is "nondescript" but there are breed standards where the bird has been imported, for example in England (imported first in 1760), Australia and the USA [32]. A large breed developed in India from nondescript local chickens is the Giriraja which has good egg laying performance and is resistant to many diseases. It has maintained many of the advantages of local chickens and is a good scavenger: it has been imported into Nepal where it is popular. Native chickens in Nepal are rather larger than most scavenging types with cocks weighing up to $2 \mathrm{~kg}$ and hens $1.5 \mathrm{~kg}$ [25]. At least 17 ecotypes of indigenous chicken have been identified but not well-characterized in Tanzania. Most of these are typical small indigenous types but two, the 'kuchi' (Figure 4) in which males weigh $2.1 \mathrm{~kg}$ and females $1.6 \mathrm{~g}$ and the 'hing'wekwe' (males $2.1 \mathrm{~kg}$, females $1.4 \mathrm{~kg}$ ) are much bigger [33].

\section{Genetics}

Domestic fowl can tolerate a wide range of environmental conditions so they are present throughout much of the world in various agro-climatic zones. At ambient temperatures above $30^{\circ} \mathrm{C}$, however, some stress is apparent. Feed intake is reduced and water consumption is increased. Over a longer period weight gain is reduced, eggs become smaller and libido is affected. Above $32^{\circ} \mathrm{C}$ and where humidity is more than 50-60 percent birds begin to suffer from alkalosis. The effects of this include thinner egg shells and poor bone formation due to lowered calcium [34]. 
Table 2: Major genes in local fowl populations with some effects on adaptation for and tolerance of tropical conditions.

\begin{tabular}{|c|c|c|c|c|}
\hline \multirow{2}{*}{\multicolumn{2}{|c|}{ Gene }} & \multirow{3}{*}{$\begin{array}{l}\text { Mode of inheritance } \\
\text { Recessive, sex-linked, } \\
\text { multiple allele }\end{array}$} & \multicolumn{2}{|c|}{ Type of effect } \\
\hline & & & \multirow{2}{*}{$\begin{array}{c}\text { Direct } \\
\text { Reduction of body size (30-10 percent) }\end{array}$} & \multirow{2}{*}{$\begin{array}{c}\text { Indirect } \\
\begin{array}{c}\text { Reduced metabolism, improved fitness and disease } \\
\text { tolerance. }\end{array}\end{array}$} \\
\hline$d w$ & Dwarf & & & \\
\hline $\mathrm{Na}$ & Naked neck & Incomplete dominance & $\begin{array}{l}\text { Loss of neck feathers, reduction of pterylae width, } \\
\text { reduction of secondary feathers }\end{array}$ & $\begin{array}{l}\text { Improved ability for convection, reduced hatchability, } \\
\text { improved adult fitness. }\end{array}$ \\
\hline $\mathrm{F}$ & Frizzle & Incomplete dominance & Curling of feathers, reduced feathering & $\begin{array}{l}\text { Decreased fitness under temperate conditions, } \\
\text { improved ability for convection. }\end{array}$ \\
\hline $\mathrm{K}$ & Slow feathering & $\begin{array}{l}\text { Dominant, sex linked, } \\
\text { multiple allele }\end{array}$ & Delay of feathering & $\begin{array}{l}\text { Reduced protein need, reduced fat deposition when } \\
\text { young, increased heat loss during early growth, } \\
\text { reduced adult viability. }\end{array}$ \\
\hline id & Non-inhibitor & $\begin{array}{l}\text { Recessive, sex-linked, } \\
\text { multiple allele }\end{array}$ & Dermal melanin deposition in skin and shanks. & Improved ability for radiation \\
\hline $\mathrm{Fm}$ & $\begin{array}{l}\text { Fibro- } \\
\text { melanosis }\end{array}$ & $\begin{array}{l}\text { Dominant with } \\
\text { multifactorial modifiers }\end{array}$ & $\begin{array}{c}\text { Melanin deposition all over the body, on sheaths of } \\
\text { muscles and nerves, on tendons and mesenterium and } \\
\text { in blood vessel walls. }\end{array}$ & $\begin{array}{l}\text { Protection against UV radiation, improved radiation, } \\
\text { increased packed cell volume and plasma protein. }\end{array}$ \\
\hline $\mathrm{O}$ & Blue shell & Dominant, sex linked & Deposition of blue pigment (biliverdin IX) into egg shell. & Improved egg shell stability \\
\hline
\end{tabular}
Source: [37].

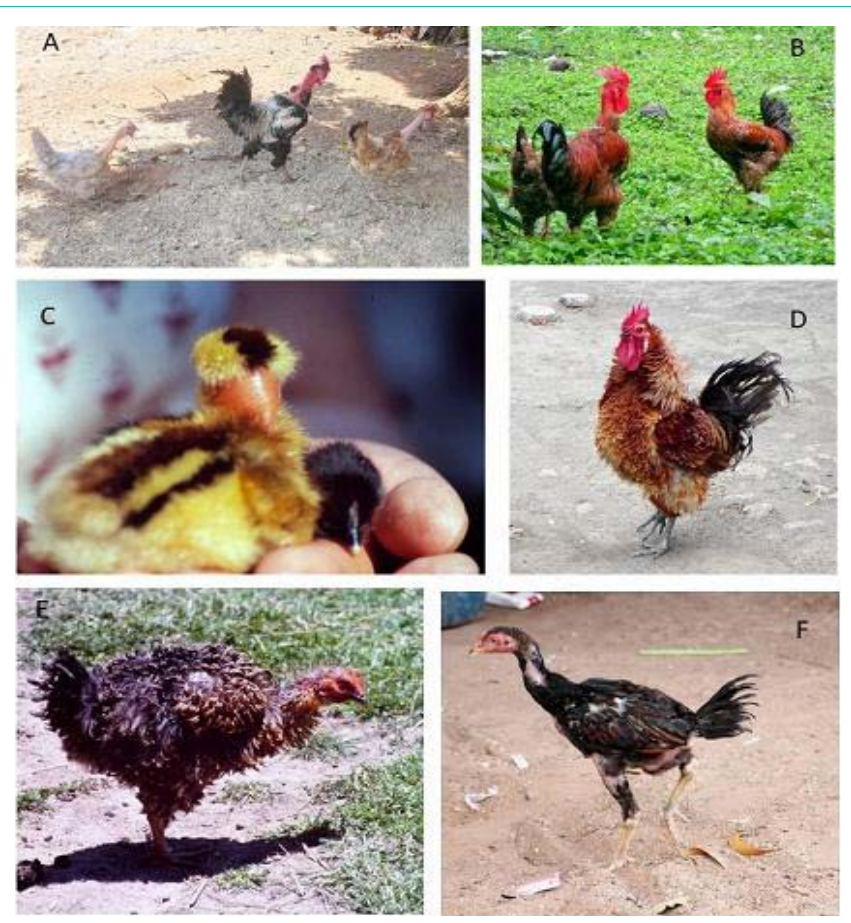

Figure 5: Adaptations to tropical conditions in domestic fowl: A) Naked neck (Na gene) cock and hens, National Artificial Insemination Centre, Lusaka, Zambia, 30 September 2010; B) Naked neck (Na gene) and standard roosters, Livinston, Guatemala, 9 February 2014; C) Naked neck (Na gene) in a very young chicken, Slavonia, Croatia, 29 May 1994; D) Frizzle feather ( $F$ gene) in a local domestic fowl, Lake Nicaragua, Nicaragua, 1 February 2014 E) Naked neck (Na gene) and frizzle (F gene) combined in a chicken, altitude 4100m. La Raya, Peru 6 February 1991; F) Slow-feathering pullet (K gene), Monkher, Cambodia, 1 February 2016.

Development initiatives in the past have emphasized genetic improvement, usually through the introduction of exotic genes, arguing that improved feed would have no effect on indigenous birds of low genetic potential. There is now, however, a growing awareness of the need to balance the rate of genetic improvement with improvement in feed availability, health care and management.
There is also an increased recognition of the potential of indigenous breeds and their role in converting locally available feed resources into sustainable production $[35,36]$.

In general terms there is little quantitative information on the genetic make-up of traditional fowl breeds. There is, however, great variation in physical and morphological characteristics and it seems likely that similar variation exists in adaptive and production traits that are in wait of identification and exploitation. Several genes could be better exploited to increase the performance of indigenous poultry (Table 2, Figure 5). The most clearly expressed adaptive genes are the one for Naked Neck $(\mathrm{Na})$, Frizzle Feather $(\mathrm{F})$ and dwarfing $[37,38]$. The genes are recorded from almost every location in the tropics and subtropics where any even superficial studies of native fowl populations have been undertaken [39-42]. In addition to better heat tolerance there is evidence that these genes enhance immunocompetence against several diseases, and confer faster growth rates on their bearers.

The naked neck and frizzle genes are the ones that have attracted most attention for incorporating in "improved" breeds as an adaptation to heat stress [43-45]. Birds with the naked neck gene may be given a special name among the general population as, for example, in Senegal where it is known as 'n'daare' [10] and in Ethiopia where it is known as 'melata' [46]. The effects of the frizzle feather gene are generally positive on performance and are probably further enhanced by the habit of birds carrying this gene of rubbing off and breaking their feathers [40,43,47-49].

\section{Management}

In all LIFDCs traditional poultry are left to scavenge and there is usually very little "husbandry". Welfare is hardly ever considered. Very little food is provided. Health care is minimal to non-existent. Under these husbandry conditions large size is almost certainly a disadvantage which is probably the main reason that most scavenging poultry are genetically small.

\section{Housing}

Many small-scale producers do not provide housing for their 

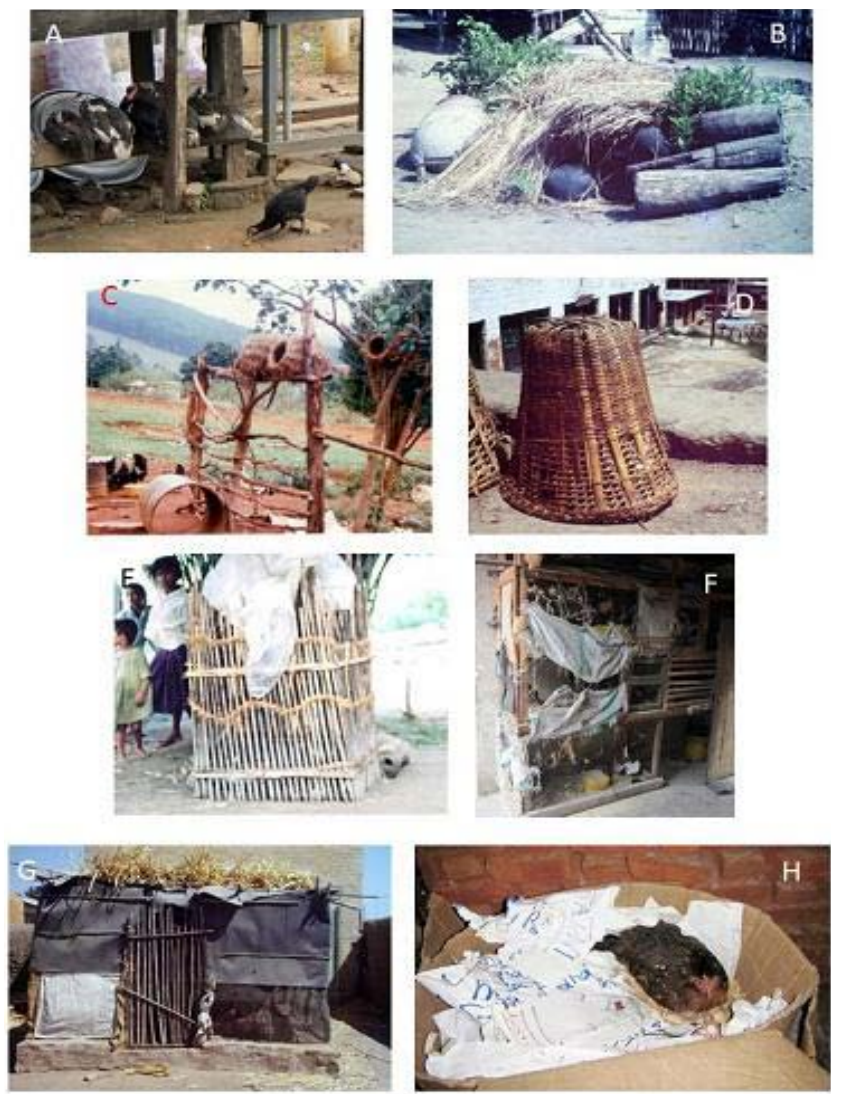

Figure 6: Housing for small-scale poultry: A) Guinea fowl roosting site, Accra, Ghana, 8 August 2014; B) Primitive shelter for chickens, Institut Togolais de Recherche Agronomique, Avetonou, Togo, 25 February 1987; C) Raised roosting box, Mbabane, Swaziland, 20 April 1986; D) Woven basket of reeds, Hetauda, Nepal, 3 July 1996; E) Reed box for ducks, Chitwan (altitude 170 masl), Nepal, 22 September 1994; F) Purpose-built wooden brooding/ roosting station, urban house compound, Iringa, Tanzania, 18 January 2013; G) Chicken house of scrap materials, El Huda, Sudan 9 November 1988; H) Hen's choice of brooding site, house compound, Iringa, Tanzania, 18 January 2013.

birds. Poultry therefore often roost in trees or shrubs, in the eaves or on the roof of their owner's houses or in some place that takes their fancy. If shelter is provided it ranges from something very primitive to more elaborate and imaginative structures. Such housing usually makes use of materials appropriated by the owners (it is not only the birds that scavenge) including timber, leaves, maize stalks, scrap metal, discarded tyres and thatching material (Figure 6). Feed troughs, drinking vessels, nest boxes and perches for roosting may also be provided [50]. A place for brooding is usually not provided in the scavenging system where birds are left to choose a place convenient to them. In contrast to the generally cavalier attitude to chicken housing, housing for pigeons over much of the world shows considerable effort to keep the birds at home (Figure 7).

\section{Nutrition and feeding}

Several African studies have shown that scavenged household scraps are the main source of feed for free ranging traditional poultry [51-53]. Many other quantitative studies of actual feeding and feed intake in small scale poultry in the LIFDCs have been made. One study in Sri Lanka [31] showed that 70 percent of total intake was
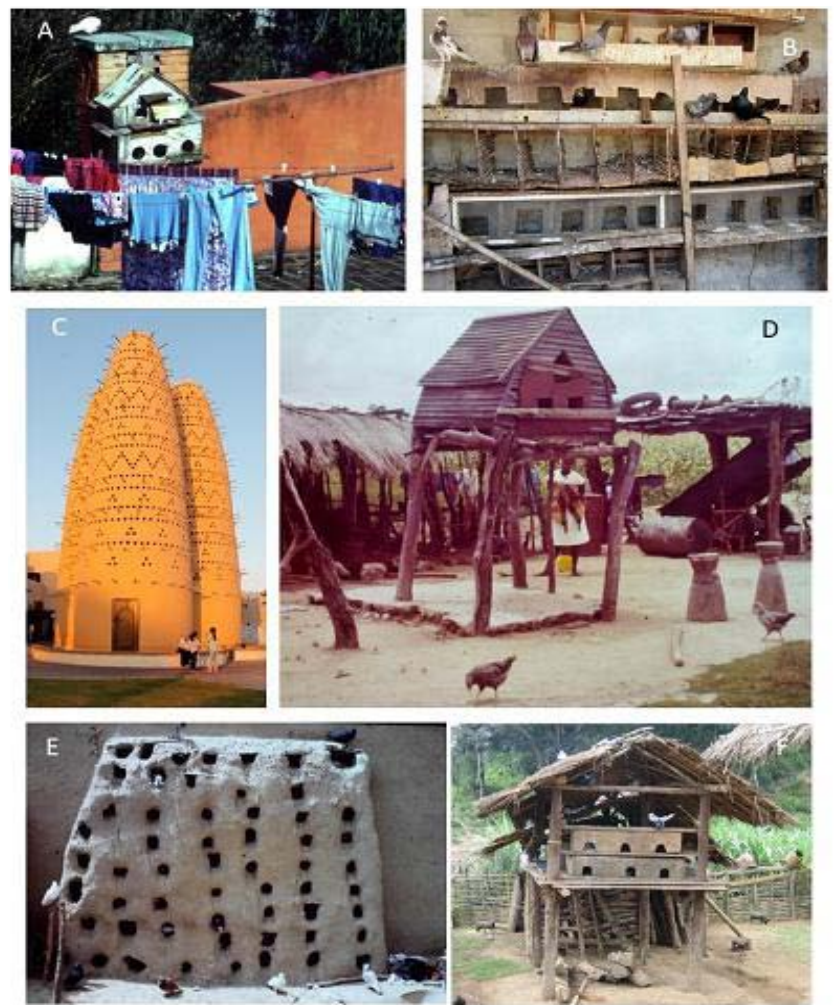

Figure 7: Perching places for pigeons: A) Urban roof top, Khatmandu, Nepal, 12 September 1994; B) Wooden next boxes in house compound, Kimbiji, Dar es Salaam, Tanzania, 29 January 2013; C) Pigeon tower (Arabic = 'burj hamam'), Dohar, Qatar, 18 February 2016; D) Raised loft, Mangwende, Zimbabwe, 20 February 1986; E) Mud housing with individual slots, Niono, Mali, 10 May 1985; F) Raised loft with thatched roof, Xieng Khoang, Lao PDR, 26 June 2007.

of household refuse, 13 percent grass shoots, 8 percent insects and other small animal life and 7 percent paddy rice. Some 27 percent of the household refuse was cooked rice, 30 percent coconut residue, 8 percent broken rice and 35 percent other items. In Venda region in South Africa chickens consumed grains, kitchen waste, seeds from the environment, plant materials, worms and insects. Household waste accounted for 78.6 of intake in autumn, 91.1 percent in winter and 75.8 percent in spring. Over the same three seasons materials of animal origin, including insects and worms, accounted for 7.4 percent, 10.4 percent and 16 percent of intake. The crude protein level of crop contents of adult chickens in all seasons and the calcium and phosphorus levels in winter corresponded with the requirements of poultry for maintenance and growth but not egg production [54]. It has been suggested, however, that scavenged feeds provide only 60-70 percent of nutrient requirements. Thus, although scavenging has considerable advantages in small-scale systems the lack of feed supplementation is a major limiting factor [6].

One of the major nutritional problems of traditional poultry production is the access - rather the lack of - that birds have to water. Many parts of the world where these birds are an important source of animal protein and income for smallholder families are hot and arid or semiarid. Yet it is unusual to supply water systematically to the birds. Restricted water intake adds to the heat stress of birds and contribute to reduced feed intake, which may already be considerably 


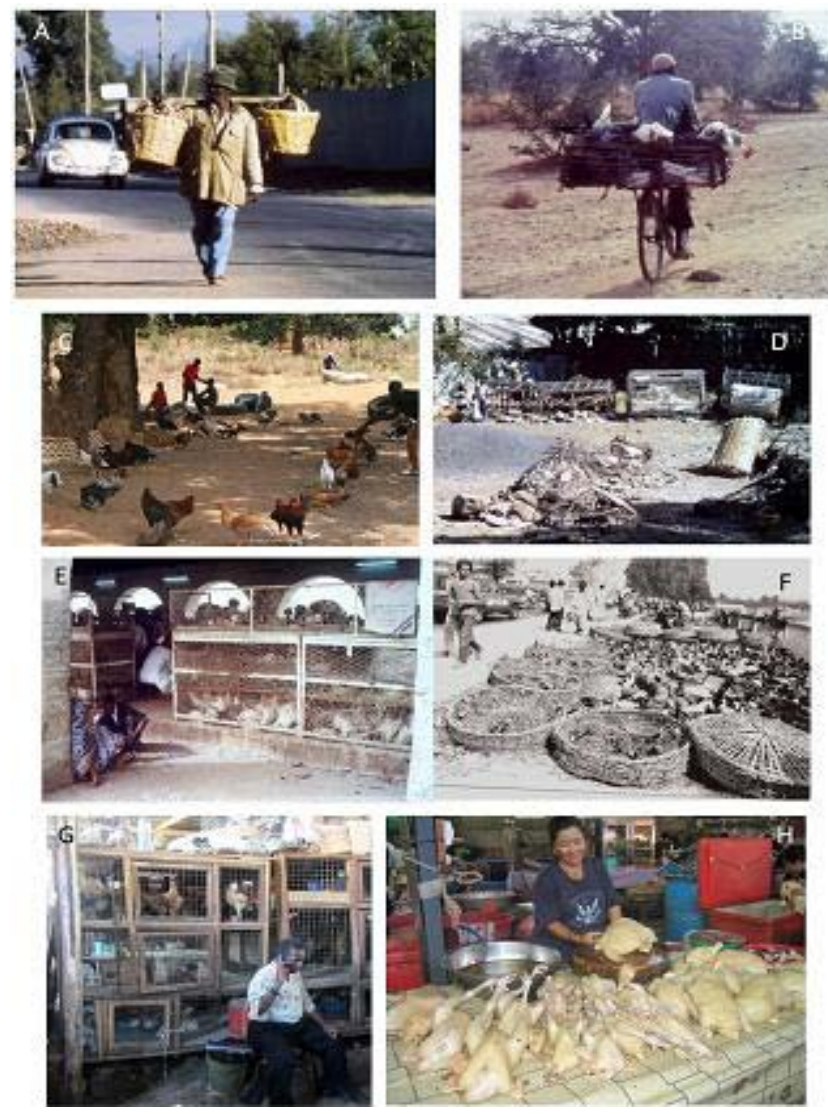

Figure 8: Aspects of marketing: A) Egg collector, Addis Ababa, Ethiopia, 10 December 1984; B) Chicken market middleman, Ouahigouya, Burkina Faso, 10 May 1985; C) Roadside chicken sales, Kingolwera, Tanzania, 3 October 2012; D) Informal terminal urban market, Addis Ababa, Ethiopia, 10 December 1984; E) Formal municipal market, Khartoum, 9 January 1988; F) Open air collection market at Hindu 'Dasein' Festival, Kathmandu, Nepal, 10 October 1994; G) Urban terminal consolidator for chickens, pigeons and rabbits, Kisutu, Dar es Salaam, Tanzania, 4 February 2013; H) The end of the game, chicken, duck and goose carcasses, formal market, Vientiane, Lao PDR, 9 July 2007.

less than is required to encourage higher levels of output. Reduced feed intake generally also results in reduced intake of minerals and vitamins. Calcium intake may be especially low in some areas.

\section{Health and disease}

Mortality is a major constraint to increased production and productivity in smallholder traditional poultry production. In Sri Lanka mortality to 70 days has been shown to be 70 percent of chickens hatched [31]. Chick survival to eight weeks of age in Ethiopia was $51.3 \pm 13.3$ per cent in the range 12.5 percent at 8 weeks of age: in that study about half eggs produced were incubated in order to replace losses of chicks, making reproduction for replacement the main focuses of chicken keepers [55]. In Mali deaths to eight weeks of age were 56 percent [30]. In spite of high mortality rates, however, native birds have higher survival rates than "improved" breeds would have in the same environment. In Mexico, for example, an overall mortality rate of 43.2 percent was recorded from birth to 140 days of age but crosses of local with exotics had considerably lower mortality than pure exotics [56].
Many potential health problems go largely unrecognized or are ignored. Such is the case with Mycoplasma gallisepticum which causes chronic but often superficially imperceptible respiratory problems [57]. Other diseases such as fowl cholera, fowl typhoid, fowl pox and pullorum disease (or bacillary white diarrhoea) together with under and malnutrition have severe adverse effects on the already low output of traditionally managed poultry. Internal and external parasites also cause reduced output. Among the latter are lice Linognathus spp., scaly leg mite Kaemidecoptes mutans, soft tick Argas persicus and fleas [58,59]. Several social problems that are common and widespread in intensive commercial systems, including cannibalism, feather pecking and egg eating, are very uncommon in traditional production systems.

Newcastle disease is the most serious epizootic poultry disease in most LIFDCs where it is constantly present and can kill up to 80 percent of unvaccinated family poultry flocks. The causal virus is carried by world birds which have virtually open access to village flocks as biosecurity is minimal or non-existent in these systems [60]. In Nigeria it devastates poultry flocks every year [61,62]. In Botswana it is more prevalent in backyard systems than in enclosed ones [58] but this is almost certainly the case everywhere as intensive production systems invariably vaccinate their stock regularly. Problems in the past with traditional systems have been related to delivery of delicate vaccines in the absence of an adequate cold chain. The use of new thermostable vaccines that can be delivered in a simple manner in food or water will contribute to a revolution in traditional small scale production by greatly reducing mortality although birds may have to be vaccinated on a regular basis to maintain immunity [63]. Such vaccines include the V4 strain [64] as well as the I2 ("eye two") which can easily be produced with minimum facilities in small laboratories using local eggs (already infected with local pathogens!) as the base material [65-67].

In recent years Highly Pathogenic Avian Influenza (HPAI) has become a problem in poultry production $[68,69]$. HPAI, as for Newcastle disease, is present throughout the world [70,71] and in many species of poultry [72]. In Indonesia the seroprevalence of HPAI among ducks that were not vaccinated against the disease was 2.6 percent but was only 0.5 percent in fowl in contact with ducks and duck flocks were 12.4 times more likely than chicken flocks to have seropositive birds [73]. Outbreaks of HPAI and especially the $\mathrm{H} 5 \mathrm{~N} 1$ variant have resulted in most countries in the imposition of emergency control measures including intensive culling and restrictions on production, slaughter, movement and marketing of poultry. These measures are predicated on improving biosafety and reducing the risk deaths in humans and poultry. They are also of greater benefit to industrial poultry sector than to the smallscale traditional or semi-industrial sectors [74,75]. Compulsory vaccination is also implemented in some countries and some also ban poultry production altogether [76].

\section{Products and production}

Much of the output of traditional small scale production is consumed at home. The main marketed products are live birds and eggs. These products are sold by the "piece", there is usually no attempt at grading and little at processing or preparation to provide a clean or more attractive product. Meat and eggs from local fowl almost always 


\section{INDIGENOUS POULTAY}

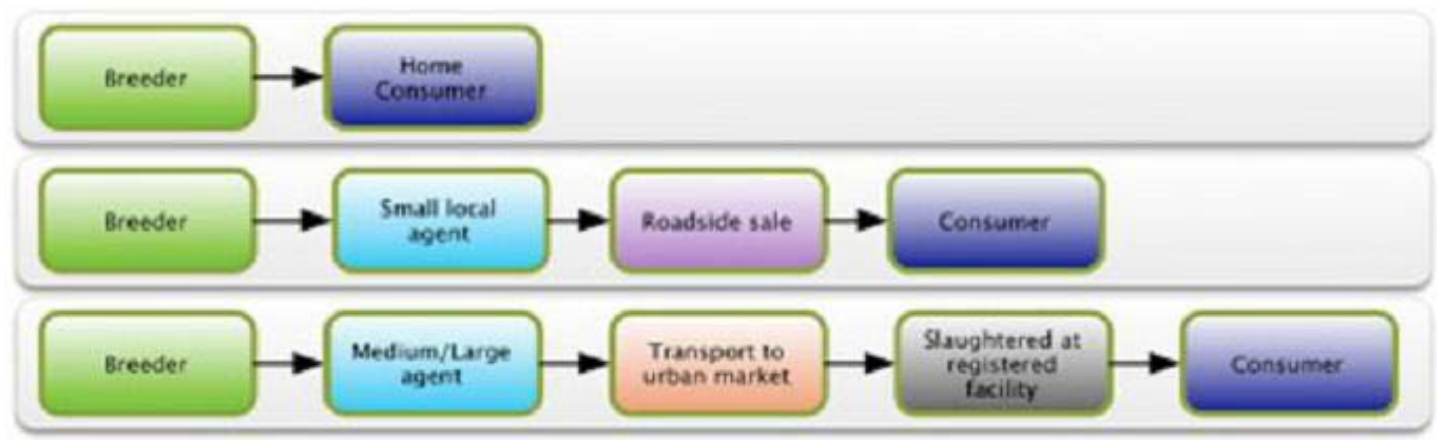

Figure 9: Generalized marketing paths for poultry from producer to consumer.

command a price that is higher than products from intensively reared exotic birds. In Sri Lanka the 10-20 percent premium of local eggs is paid for flavour, colour and a perceived higher nutritive value [31].

It is generally considered that traditional native breeds are of low productivity. A distinction needs to be made, however, between "productions" or -- more correctly -- output, which implies consideration only of that which is produced and "productivity", which considers not only that which is produced but also that which is used (i.e. inputs). Under free ranging conditions the output of traditional fowl is undoubtedly low in terms of growth and number of eggs per hen per year but any production is gained with minimal labour and rearing inputs and thus at low cost. In this scenario native fowl might well compare favourably with so-called improved breeds as indeed has been shown for such comparisons for cattle and other quadruped species.

The reproductive cycle of traditional native fowl is characterized by late ages at first egg laying, small clutch sizes, low annual egg production ("hen housed average") and limited lifetime production. They usually, however, go broody very easily, sit tightly on their eggs, need little in the way of feed or attention when they are brooding and are good mothers to their chicks in the early post hatching period.

Early weight gains are often negative [29] and when they turn positive at about 7 days remain low. In Mali average daily gains were only $4 \mathrm{~g}$ [30]. Average pooled weight gains of ten ecotypes of chicken in Tanzania were $2 \mathrm{~g} / \mathrm{d}$ for the first month and $5.6 \mathrm{~g} / \mathrm{d}$ for the second month [77]. In Sri Lanka average live weights at 70 days were $313 \mathrm{~g}$ in the range 142-492 $\mathrm{g}$ [31] with an implied average daily gain from hatching of 3.86g. Production by Creole fowl in Guyana [78] in terms of both egg production and growth rate is similar to that observed for many other areas.

Mean egg laying performance of hens in Ethiopia were 17 eggs for the first, 21 for the second and 25 for the third and subsequent clutches. An average of $2.6 \pm 0.06$ clutches per year per hen were laid. Hatching rate was $70.5 \pm 10.6$ percent ranging from $30-90$ percent $(n=250)$ [55]. In Sri Lanka first eggs were laid at 211 days when the pullets weighed $1160 \mathrm{~g}$ (equivalent to 93 percent of final mature weight). The first laying period lasted $34 \pm 13$ days and produced about 20 eggs weighing on average $48 \mathrm{~g}$ : there were only three such laying periods in the year. The egg weights are much higher than the 30-35 g normally found in native fowl especially for bird of such mature weight. The hatching rate of these Sri Lanka eggs was $67 \pm$ 32 percent [31]. In Tanzania egg weights were $42.5 \mathrm{~g}$ - again rather heavier than most other records - with hatchability of 62 percent [77].

Zimbabwe local fowl lay up to three "clutches" per year each of 8-22 eggs but total annual production does not exceed 60 eggs [79]. There is a peak in egg laying in April and May possibly because the weather is becoming cooler at this time but perhaps also because nutritional status improves as a result of spilt grain in nearby fields and around the house from harvesting and threshing operations. Hatchability of these native eggs in Zimbabwe is as high as 80 percent.

A longitudinal study in Mali showed that clutch sizes were in the range 8-12 eggs with an average weight of $34.4 \mathrm{~g}$ and the cycle between one clutch and the next being 92 days [30,52]. Annual egg production was only 35 eggs but this was about 118 percent more than the average body weight of the hen. Hatchability was 69 percent which together with high mortality and some offtake for home consumption or sale meant that only 10 percent of eggs laid produced an adult breeding bird. Similar results to these were also found in western Sudan [29], Senegal [41], Nigeria [80], Kenya [81] and Rwanda [82].

A total of 2039 Guinea fowl eggs were incubated by surrogate hens in Zimbabwe. The average number of eggs laid by Guinea fowl hens was $42 \pm 26$ of eggs. Egg weights ranged from $24.7 \mathrm{~g}$ to $41.3 \mathrm{~g}$. The hatching rate was 71 percent but many keets were weak at hatching: 489 keets survived to two weeks but only 175 keets survived to "weaning" at six weeks. Day-old weight ranged from $22.7 \mathrm{~g}$ to $28.6 \mathrm{~g}$. Live weight at 16 weeks was $148 \mathrm{og}$. Losses were due to external parasitic infestation, predation by snakes, cats and dogs, starvation and theft. A few eggs only were consumed whereas others were lost through breakage. It was inferred from the results that Guinea fowl productivity was compromised by low hatchability, excessive mortality and general mismanagement and that improved attention to egg collection, storage and proper care of keets would substantially enhance productivity [83]. Similar findings and conclusions on small-scale Guinea fowl production were found in Nigeria [84] and Ghana [85].

Flock sizes of $7.7 \pm 3$ Muscovy ducks (1 drake to 3 ducks) were recorded Dolisie city in Congo Brazzaville and in all flocks birds were kept production of ducklings, meat and eggs. Clutch size was $13.2 \pm 5$ 


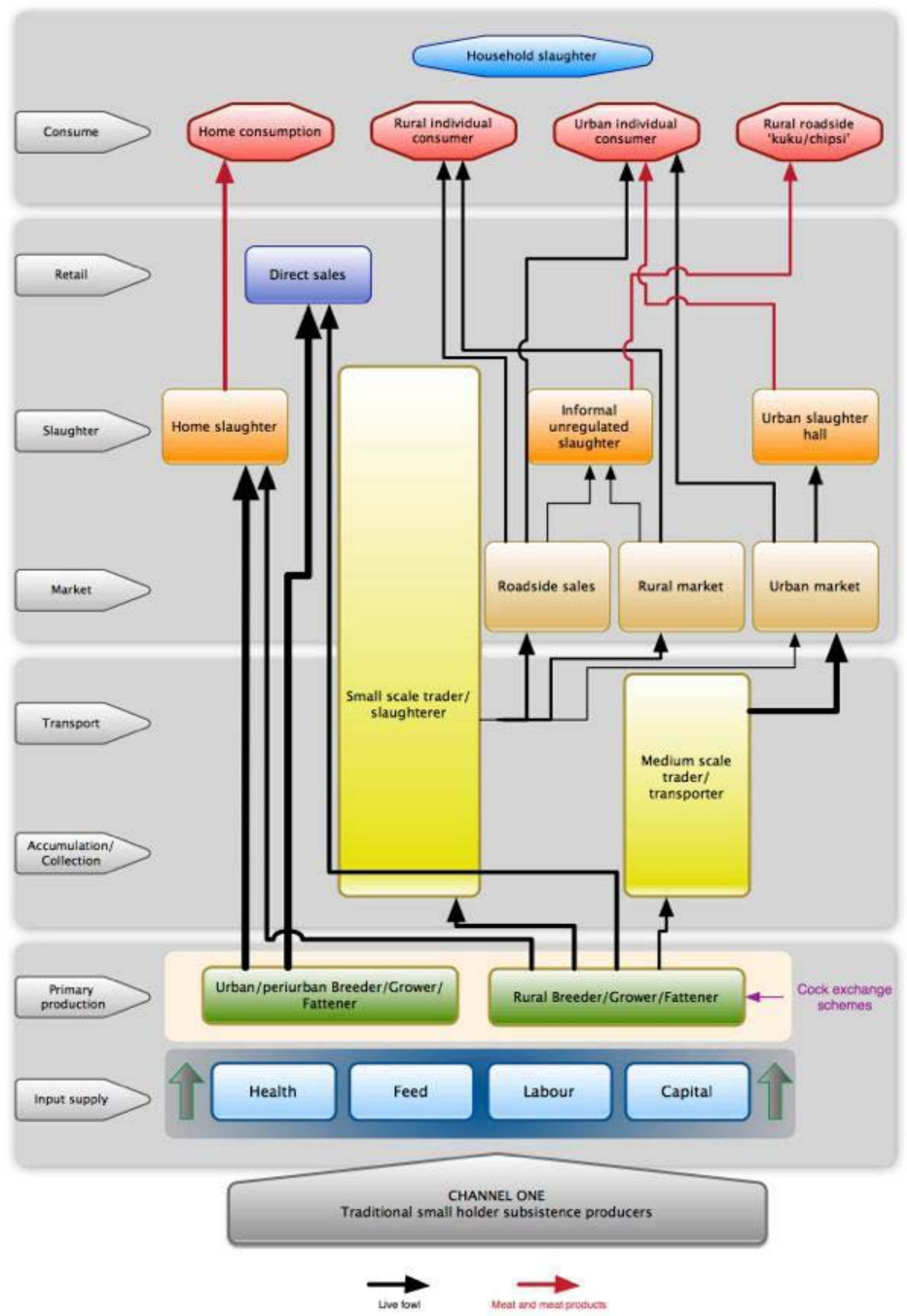

Figure 10: The small-scale poultry value chain. 
eggs. Hatchability was 80.5 percent nut there was 80 percent mortality in ducklings due to poor feeding, lack of veterinary care and poor housing. Eggs and live ducks were sold in response to family needs rather than market price. Some 80 percent of owners were men and as an exotic bird there were no cultural beliefs or taboos inhibiting duck production [86]. In India duck rearing by the rural poor is for egg production only with more than 90 per cent of ducks being local 'desi' type that are resistant to disease but small and produce less than 150 eggs per year.

Ducks and geese are minor species of poultry in terms of numbers in Turkey but are spread over most of the country. They are owned mainly by resource-poor smallholder farm families to whom they contribute animal protein and thus improve welfare. Only one indigenous breed of each species is recognized by Government but owners distinguish various colour morphs of both ducks and geese and these show differences in egg weights and growth traits. Some exotic Pekin ducks were imported in 1984 and Muscovy ducks at an unknown time. Most production is for home consumption so there is little internal market activity but there have been sporadic exports and exports of duck meat and goose foie gras. In terms of perceived value of output owners considered meat was 15 percent of the total in ducks but only 10 percent in geese, duck and goose eggs were both valued at 10 percent, in terms of "culture" (i.e. as a hobby) ducks rated 15 percent whereas this was 20 percent for geese, feathers were considered to be worth 20 percent in ducks but 40 percent in geese and environmental management was considered to be 40 percent of duck output but only 20 percent for goose. Egg weights of local duck types were in the range 68.6-76.3 g with hatching weights in the 41.7$46.2 \mathrm{~g}$ with hatchability of $33.5-78.5$ per cent. Weights at 12 weeks varied from $1.8 \mathrm{~kg}$ to $2.1 \mathrm{~kg}$ depending on the strain. Duck dressed carcasses were 71.3 to $73 . s$ percent of live weight at slaughter. Gees lay eggs in January/February and June/July with individual production from as few as eight to as many as 60 eggs. Egg weights of young geese averaged $144.2 \mathrm{~g}$ with a fertility of 60.5 percent and hatchability of 22.2 percent: eggs of older bird's weight up to $200 \mathrm{~g}$. Some geese continue laying until 10 years of age. Gosling live weight at hatching was in the range of 71.5 to $92.4 \mathrm{~g}$ with 12-week weights being of the order of 2.4 to $2.7 \mathrm{~kg}$. Dressing percentages of the various strains of geese were in the range were around 70 percent but here, as for ducks the dressing percentage would be lower if the giblets were removed. Feathers and down are used locally in padded winter clothing, in mattresses, pillows, bed quilts and in soft furnishings [26].

Egg weights of brown and white indigenous geese types reared extensively in Bangladesh were $131.85 \pm 1.70 \mathrm{~g}$ in a clutch size of $7.42 \pm 0.08$ eggs. The first clutch was laid at $313.22 \pm 3.03$ days, three clutches were laid per breeding season and each cutch was incubated for $30.30 \pm 0.07$ days. Weight at day was $95.45 \pm 0.88 \mathrm{~g}$ and at 10 months was $3.65 \pm 0.06 \mathrm{~kg}$. Males were heavier than females at all age groups except day-old but body weights did not differ between brown and white types [87].

Pigeons are an important and well-liked item of the human diet in Sudan (as indeed in most of the Arab world). Management is, however, minimal and hand feeding is rarely practiced. Housing is provided but is of a kind peculiar to the country and consists of a raised platform of straw with a conical roof that provides a communal area for several pairs of birds. Under simulated traditional conditions in Western Darfur in Sudan pigeons laid their first eggs at 132 days of age and thereafter laid clutches of two eggs at intervals of 43 days or a total of 17 eggs per year. Weights of eggs from first clutches were $11.5 \mathrm{~g}$, increasing to $17.1 \mathrm{~g}$ in subsequent clutches. Egg fertility was 88 percent and hatchability was 81 percent. Pigeons exhibited very rapid growth to 18 days when fed on breast milk followed by a slowing down as this feed source dried up and squabs left the nest at 25 days. At 25 days young pigeons weighed about $240 \mathrm{~g}$ and reached an asymptote of about $280 \mathrm{~g}$ at 50 days [29].

\section{Marketing}

Meat and eggs from intensively raised hybrid stock are considered by many traditional consumers to have less flavour, and the meat to have too soft a texture. Consumers will thus often pay a higher price for village-produced poultry meat and eggs. Thus, for rural family poultry keepers, it is more appropriate to maintain and improve local birds to meet this demand. Birds and eggs are marketed on an ad hoc basis usually when the need arises for cash to pay current household expenses or they contribute to larger expenditure such as medical treatment of school fees. Marketing is a very informal and hugely varied exercise (Figure 8). Women tend to dominate in production and selling but are mainly men. Cultural events and religious festivals affect local demand and producer and consumer prices.

The flow of products (live birds, meat, eggs) from producers to consumer varies from the extremely simple to the more complicated (Figure 9). The value chain involves multiple participants working at various levels (Figure 10). The local channel begins with the producer selling poultry products to retailers who serve the needs of local consumers. In most areas, local consumers also buy directly from producers. The other marketing channel involves wholesalers. They buy poultry products directly from producers and sell to retailers who are based in urban centers where urban-based consumers are located. Weak horizontal and vertical links affect the whole chain. Participants and enterprises do not cooperate or coordinate (indeed the latter seems to be a totally alien concept). The capacity to influence domestic policy as well as more mundane aspects such as collective access to inputs and other service is thus limited. In summary both horizontal and vertical integration remain marginal. In general the indigenous poultry value chain can be considered to be a "market-type governance" with many producers and many traders and local retailers. Relationships among stakeholders in the value chain are mainly determined by the price at which the product is sold. Coordination is required for the whole chain encompassing all participants to generate communication and trust. The value chain is largely driven by market forces with respect to prices and their upand down-stream effects on supply and operations throughout the chain. The major issues include lack of governance, poor supervision of lower-end associations, too many small operators and small transactions, lack of market coordination, unclear and conflicting roles and mandates in the official administration, weak industry associations [88].

\section{Economic and socioeconomic aspects}

In many areas small-scale poultry production is undertaken to provide the household with meat and eggs [89]. In some areas more than 70 percent of eggs produced within smallholder traditional systems may be eaten by the household or the extended family [31]. 


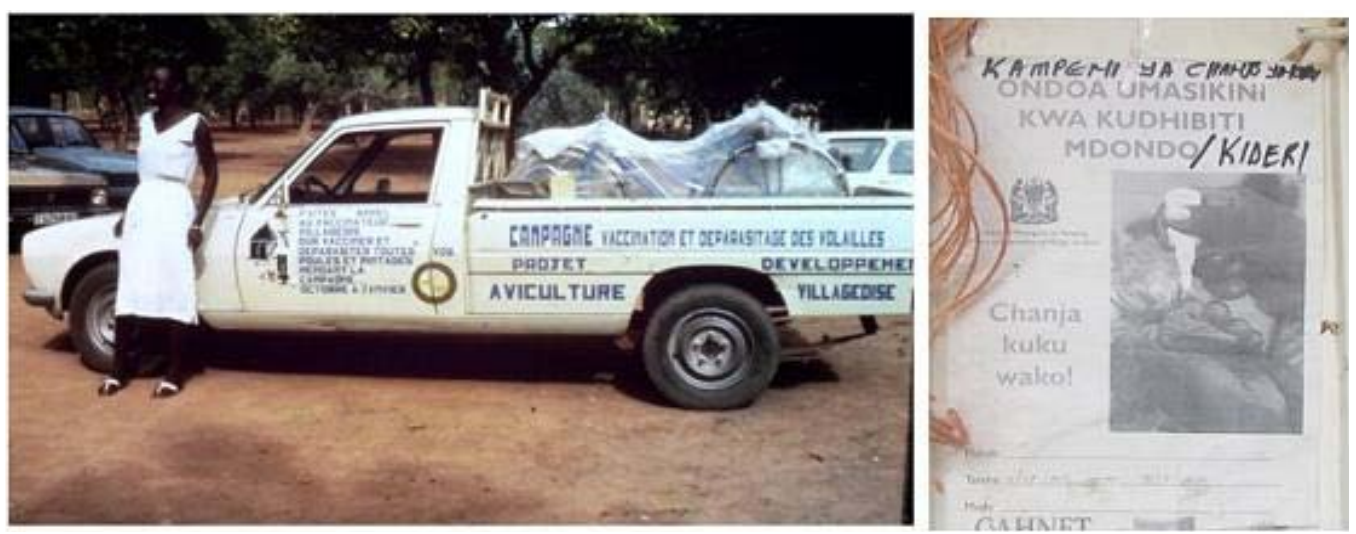

Figure 11: Government projects to control diseases in poultry: A) Village Poultry Development Project, Ouagadougou, Burkina Faso, 10 May 1985 ; B) Vaccination campaign, Babati, Tanzania, 20 January 2013 (The message is "Control the disease, vaccinate your chickens").

Elsewhere, however, there are taboos against eating eggs especially by pregnant women $[51,52]$. The proportion of birds and eggs retained for household consumption does, however, vary from place to place. In Ethiopia, for example, 50 percent of birds and 40 percent of eggs are sold to generate cash [90].

Small scale poultry generate employment, add to food security and make a considerable contribution to gender equality [91,92]. Additional income and increased domestic meat supply as the primary reasons for keeping poultry in the backyard in Ghana [93]. In Zimbabwe almost all cattle are owned by men but 70 percent of indigenous poultry are owned by women. When asked to rank livestock species in order of importance in terms of contribution to their daily life and food provision, women ranked indigenous chickens first in a list of 10 species, cattle second and goats third but, perhaps somewhat surprisingly, men ranked indigenous chickens second after cattle [79]. Even where native poultry are not owned by women, they and their children often have preferential access to eggs and meat and so are able to improve the quality of their diets. Women also usually sell birds and eggs and as the amounts of monetary return are small (and therefore perhaps beneath contempt for men) may keep the cash so generated and use it for purchase of small essential food and household items [13,51,52,94].

There are few to no costs involved in traditional smallholder scavenging poultry production. The output therefore is all "profit". Occasional costs may, however, be incurred for vaccination for Newcastle disease, for example, (although in many developing countries the state veterinary services or charitable Non-governmental Organizations provide vaccines free) but the economic rate of return on this intervention has been shown in Mozambique to be highly positive [95] as it has in Myanmar [96]. Such returns are enormous compared to other forms of investment or expenditure on animal production.

In Tigray in northern Ethiopia poultry significantly contributed to the livelihoods of poor households: economically as starter capital, as a means to recover from disasters, as an accessible protein source and for disposable income and exchange purposes and socio-culturally for mystical functions, hospitality and exchange of gifts to strengthen social relationships. Relatively wealthy households with good market access had significantly more poultry than those in remote areas and the relatively poor. Male-headed households kept larger flocks than female-headed households [11].

\section{"Improving" small-scale poultry production}

Policy, where such a situation exists in the LIFDCs, in the past has been to "upgrade", absorb or replace native breeds with exotics. Increasing awareness of the value of native genetic resources and such well publicized initiatives as the Convention on Biological Diversity which resulted from the Rio "Earth Summit" are, however, beginning to have some effect on this type of activity. The time is perhaps not far distant when active (and adequately financed) efforts will be made to make more rational use of these birds.

Initiatives to improve the status of small-scale family poultry production started in 1961 [97,98]. Most of these simply supplied exotic breeds for cross breeding. The overall goals were to improve the nutritional status of the rural population through increased availability of eggs and meat and to increase income to alleviate poverty. These aims have yet to be achieved due to disease outbreaks, difficulties in replacing local cockerels, poor adaptability of introduced breeds and lack of knowledgeable and skilled manpower. Attempts still continue, however, to "improve" the genetic worth of indigenous poultry. In Africa these have often taken the form of cock replacement schemes (usually known in French speaking countries as "Opération Coq") within the traditional environment. In India the Government Poultry Breeding Programme has been involved in cock replacement programmes amongst its other activities. India presents one of the few examples of genuine within-breed improvement of native birds where the productivity of the Kadaknath type has been considerably improved without apparently adverse effects on its adaptive characteristics [99].

The Rhode Island Red is perhaps the most commonly used exotic breed but New Hampshire, Australorp and Orpington are others. These attempts have rarely achieved a sustained impact mainly because the introduced cocks have rapidly succumbed to local diseases, starvation or the fatal attacks of local cocks that are perhaps only one third or one quarter of the size and weight of the introduced birds. This last cause of loss is in spite of attempts to limit the effects by the development community by insisting on exchange programmes 
whereby two or even three local birds must be surrendered for an exotic one.

Similar attempts have met with similar failure levels in other areas of the tropics such as Southeast Asia [100]. Many farmers do not in fact like exotic birds: in the hills of eastern Nepal after several years of intensive effort only 1.4 per cent of the fowl population consisted of crossbreds or pure exotics compared to 15 percent of improved pigs in the same area [25]. Production of individual native birds can be greatly increased -- perhaps three fold or more -- under controlled conditions [101] without any attempt at genetic modification.

There are both technical and administrative challenges to improved and increased production of all species ducks and geese but opportunities exist for enterprise diversification, for new entrants to species that are less costly to keep and produce than many other domestic species and for processing and producing value-added products [26]. It is essential in any improvement programme to maintain the adaptive traits of the base stock. The route to improved productivity lies firstly in improving the total production environment and especially disease control - as is being done in some countries (Figure 11) - and nutrition to reduce the very high death rates and only after this has been achieved giving consideration to modifying genetic make-up.

\section{Discussion}

Traditional poultry breeds are widely distributed throughout the world in most agroecological zones. They may be less numerous absolutely and relative to improved and hybrid types in developed countries. In developing countries, with few exceptions, they continue to be dominant numerically especially in rural areas where smallholder mixed farming systems predominate. The low inputs and, consequently, low risk is one of the major advantages of indigenous poultry production. The development of village poultry should not be considered merely a technical challenge but rather one of addressing livelihood issues.

In many rural areas in LIFDCs, the vast area and a lack of resources and infrastructure often result in limited veterinary and extension services (Thieme et al. FAO, 2014). Where these exist, they are usually focused on crop or ruminant production, with little health care or advice accessible to small-scale poultry keepers. This has a negative impact on farmer access to information including details of adequate biosecurity practices, which is not a major concern in the minds of small-scale extensive poultry producers but is vitally important for increased productivity. The formation of networks of communitybased animal health workers, where training and knowledge is passed among veterinarians, governments and communities, has been found to be effective in delivering services such as vaccination and other health care as well as reporting, investigating, or controlling animal diseases (Leyland et al. 2014).

Lack of consideration of gender issues can also limit the effectiveness of extension services. It is estimated that female farmers receive only 5 percent of agricultural extension services that only 15 percent of extension workers are women; and that only 10 percent of agricultural aid goes to women. This situation indicates the current bias towards men in the agriculture sector. Most of the training, communication and extension materials is directed at men whereas women, who are the main participants in small-scale poultry production systems receive a fraction only of the information they need. Lower literacy levels among women also decrease the utility of written communications.

There are technical, financial and administrative challenges to improved and increased small-scale production. Opportunities exist, however, for enterprise diversification, for new entrants to rear species that are less costly to keep and produce more than many other types of domestic livestock as well as for processing and producing valueadded products. Major constraints with which small-scale production systems have to contend include poor management conditions and poorly developed marketing structures for the products. The skills of small farmers in all aspects of poultry management must be improved through training and education. Poultry farmers should also be provided with credits or loans, taking into account the economic circumstances and socio-cultural context in which the beneficiaries live.

\section{Acknowledgements}

All photographs are by the Author and Figure 9 and 10 were both constructed by the Author. Grateful thanks to the hundreds of colleagues and co-workers and the thousands of small-scale poultry keepers who unwittingly made this paper possible.

\section{References}

1. FAOStat. Live Animals. Rome, Food and Agriculture Organization. 2021.

2. Daghir NJ. Editor, Poultry production in hot climates. $2^{\text {nd }}$ edition. Wallingford, UK: CAB International. 2008

3. WWI. State of the World 2017: Earth ED: Rethinking Education on a Changing Planet. Washington DC: World Watch Institute. 2018.

4. NCC. Per Capita Consumption of Poultry and Livestock, 1965 to Estimated 2019, in Pounds. Washington DC: National Chicken Council. 2020.

5. Raha SK. Poultry industry in Bangladesh: ample opportunities for improvement. Proceedings of the $8^{\text {th }}$ International Poultry Show and Seminar, WPSA-BB, 2013 February 28-March 3; Dhaka, Bangladesh. 13-19.

6. Alders RG, Pym RAE. Village poultry: Still important to millions eight thousand years after domestication. World's Poultry Sci J. 2009; 65: 181 190.

7. Wilson RT. Poultry production and performance in the Federal Democratic Republic of Ethiopia. World's Poultry Sci J. 2010; 66: 441-454.

8. MAF. Agricultural Statistics Year Book 2004. Vientiane, Lao People's Democratic Republic: Department of Planning, Ministry of Agriculture and Forestry. 2005.

9. Agrisystems Ltd. Zimbabwe National Livestock Development Study: Final Phase 1 Main Report. Aylesbury, UK: Agrisystems Ltd. 2000.

10. Guèye EHF, Bessei W. The importance of poultry farming in Senegal. Anim Res Dev, 1997; 45: 82-88.

11. Aklilu HA, Udo HMJ, Almekinders CJM, Van Der Zijpp AJ. How resource poor household's value and access poultry: Village poultry keeping in Tigray, Ethiopia. Agric Syst. 2008; 96: 175-183.

12. Guèye EHF. Gender issues in family poultry production systems in lowincome food-deficit countries. Amer J Altern Agric. 2003; 18: 185-195.

13. Guèye EHF. Women and family poultry production in rural Africa. Develop Pract. 2016; 10: 98-102.

14. Wilson RT. Editor, Supply of livestock products to rapidly expanding urban populations. Seoul, Korea: World Association of Animal Production/Food and Agriculture Organization. 1995. 
15. Guèye EHF, Bessei W. The importance of poultry farming in Senegal. Anim Res Dev. 1997; 45: 82-88.

16. Wong JT, de Bruyn J, Bagnol B, Grieve H, Li M, Pym R, et al. Small-scale poultry and food security in resource-poor settings: A review. Global Food Security. 2017; 15: 43-52.

17. Thieme O, Sonaiya F, Rota A, Guèye F, Dolberg F, Alders R. Defining family poultry production systems and their contribution to livelihoods. In: Decision tools for family poultry development (FAO Animal Production and Health Guidelines No. 16). Rome: Food and Agriculture Organization. 2014: 3-8.

18. Alam MA, Ali MS, Das MG, Rahman MM. Present status of rearing backyard poultry in selected areas of Mymensingh district. Bangladesh J Anim Sci. 2014; 43: 30-37.

19. Sonaiya EB, Swan SEJ. Small-Scale Poultry Production: Technical Guide. (FAO Animal Production and Health Manual No 1). Rome: Food and Agriculture Organization. 2004

20. Crawford RD. Origin and history of poultry species. Poultry Genetic Resources: Evolution, Diversity, and Conservation. Crawford RD, editor Poultry Breeding and Genetics. Amsterdam: Elsevier Science Publishers 1990; 1-59.

21. Bay-Peterson J, editor. Catalogue of the native poultry of Southeast Asia Food and Fertilizer Technology Center for the Asian and Pacific Region (Book Series No. 43). Taiwan: Kuo Thai Color printing Co., Ltd. 1991

22. Traoré $\mathrm{H}$. Etude sur les potentialités zootechniques du Koko-Chié et du Dakiées-Chié dans le secteur de Kati (Mémoire de Fin d'Etudes) [A study of the production potential Koko-Chié and du Dakiées-Chié in the Kati area (Terminal Dissertation)]. Katibougou, Mali: Institut Polytechique Rural. 1981.

23. Shanawany MM, Banerjee AK. Indigenous chicken genotypes of Ethiopia Animal Genetic Resources Information, 1991; 8: 84-87.

24. Leroy P, Dang Vu Binh, Vu Dinh Ton, Farnir F, Pham Kim Dang, Do Duc Luc, et al. The Ri chicken breed and livelihoods in North Vietnam: characterization and prospects. J Agric Rural Dev Trop Subtrop, 2011; 112: 57-69.

25. Wilson RT. Animal genetic resources and domestic animal diversity in Nepal. Biodiv Conserv. 1997; 6: 233-251.

26. Wilson RT, Yilmaz O. The Domestic Livestock Resources of Turkey: Populations, production and pathology of ducks and geese. Int J Poultry Sci. 2013; 12: 553-560.

27. Yilmaz O, Savas T, Ertugrul M, Wilson RT. The domestic livestock resources of Turkey: inventory of pigeon groups and breeds with notes on breeder organizations. World's Poultry Sci J. 2013; 69: 265-278.

28. Ramadan S, Dawod A, El-Garhy O, Nowier AM, Eltanany M, InoueMurayama M. Genetic characterization of 11 microsatellite loci in Egyptian pigeons (Columba livia domestica) and their cross-species amplification in other Columbidae populations. Vet World. 2018; 11: 497-505.

29. Wilson RT. Studies on the livestock of Southern Darfur, Sudan. VII. Production of poultry under simulated traditional conditions. Trop Anim Hith Prod. 1979; 11: 143-150.

30. Wilson RT, Traoré A, Traoré A, Kuit HG, Slingerland M. Livestock production in central Mali: Reproduction, growth and mortality of domestic fowl under traditional management. Trop Anim HIth Prod. 1987; 19: 229-236.

31. Gunaratre SP, Chandrasiri ADN, Mangalike Hemalatha WAP, Roberts JA Feed resource base for scavenging village chickens in Sri Lanka. Trop Anim HIth Prod. 1993; 25: 245-257.

32. Floyd J. The Aseel (or Asil). Society for the Preservation of Poultry Antiquities Bull. 2001; 6: 4 .

33. Mushi JR, Chiwanga GH, Amuzu-Aweh EN, Walugembe M, Max RA, Lamont SA, et al. Phenotypic variability and population structure analysis of Tanzanian free-range local chickens. BMC Vet Res. 2020; 16: 360.

34. Etches RJ, John TM, Verrinder Gibbins AM. Behavioural, physiological neuroendocrine and molecular responses to heat stress. Daghir NJ, editor. Poultry production in hot climates. Wallingford, UK: CAB International. 1995: 31-65.
35. Horst P. Native fowls as reservoir for genomes and major genes with direct and indirect effect on the adaptability and their potential for tropically oriented breeding plans. Arch für Geflügelkunde. 1989: 53: 93-101.

36. Mtileni B, Muchadeyi F, Maiwashe A, Chimonyo M, Dzama K. Conservation and utilization of indigenous chicken genetic resources in Southern Africa. World's Poultry Sci J. 2012; 68: 727-748.

37. Horst P. Native fowl as a reservoir for genes and major genes with direct and indirect effects on the adaptability and their potential for tropically oriented breeding plans - A review. Anim Res Dev. 1991; 33: 63-79.

38. Dorny P, Baelmans R, Parmentier HK, Nieuwland MGB, Demey F. Serum haemolytic complement levels in German Dahlem Red chickens are affected by three major genes (Naked, Neck, Dwarf, Frizzled) of tropical interest. Trop Anjm HIth Prod. 2005; 37: 1-9.

39. Mathur PK, Horst P. Temperature stress and tropical location as factors for genotype $x$ environment interactions in poultry production. Proceedings of the Conference on Genotype x Environment Interactions in Poultry Production, May 9-11 1989. Jouy-en-Josas, France: Institut National de la Recherche Agronomique. 1989; 83-96.

40. Horst P, Mathur PK. Genetic aspects of adaptation to heat stress. Proceedings of the Fourth World Congress on Genetics Applied to Livestock Production. Edinburgh, UK: British Society for Animal Production. 1990; 14 286-296.

41. Buldgen $A$, Detimmerman $F$, Sall $B$, Coupère $R$. Etude des paramètres demographiques et zootechniques de la poule locale du bassin arachidier sénégalais. Bull Rech Agron Gembloux, 1992; 23: 345-356.

42. Islam MA, Nishibori M. Indigenous naked neck chicken: a valuable genetic resource for Bangladesh. World's Poultry Sci J. 2009; 65: 125-138.

43. Dorny P, Baelmans R, Parmentier HK, Nieuwland MGB, Demey F, Berkvens D. Serum haemolytic complement levels in German Dahlem Red chickens are affected by three major genes (Naked neck, Dwarf, Frizzled) of tropical interest. Trop Anim Hlth Prod. 2005; 37: 1-9.

44. Mérat $P$. Potential usefulness of the $\mathrm{Na}$ (naked neck) gene in poultry breeding. Worlds's Poultry Sci J. 1986; 42: 124-142.

45. Fathi MM, Galal A, El-Safty S, Mahrous M. Naked neck and frizzle genes for improving chickens raised under high ambient temperature: II. Blood parameters and immunity. World's Poultry Sci J. 2014; 70: 165-172.

46. Tadelle D, Ogle B. Village poultry production systems in the central highlands of Ethiopia. Trop. Anim Hlth Prod. 2001; 33: 521-537.

47. Somes RG. Pleiotropic effects of the sex-linked delayed feathering gene, $\mathrm{Kn}$, in the chicken. Poultry Sci. 1975; 54: 208-216.

48. van Haaren-Kiso $A$, Horst $P$, Zárate $A V$. Direct and indirect effects of the frizzle gene $(F)$ on the productive adaptability of laying hens. Anim Res Devt. 1995; 42: 98-114.

49. Dunnington A, Siegel PB. Sex-linked feathering Alleles $(K, k+)$ in chicks of diverse genetic backgrounds: 1 . Body temperatures and body weights. Poultry Sci. 1986; 65: 209-214

50. Ahlers C, Alders RG, Bagnol B, Cambaza AB, Harun M, Mgomezulu R, et al. Improving village chicken production: a manual for field workers and trainers. Canberra, Australian Council for International Agricultural Research. 2009.

51. Kuit HG, Traoré A, Wilson RT. Livestock production in central Mali: Ownership, management and productivity of poultry in the traditional sector. Trop Anim HIth Prod. 1986; 18: 222-231.

52. Kuit HG, Traoré A, Wilson RT. A profile of small-holder poultry production in Central Mali. Poultry production in hot climates of the Middle East and Far East, 2nd International DLG Symposium, 16-19 June 1985, GoslarHahnenklee, Germany. Frankfurt am Main: Deutschen LandwirtschaftsGesellschaft. 1985; 199-219.

53. Wilson RT. Poultry production in Sub-Saharan Africa. Outlook Agric. 1986 15: $121-127$

54. Raphulu T, van Rensburg CJ, van Ryssen JBJ. Assessing nutrient adequacy from the crop contents of free-ranging indigenous chickens in rural villages 
of the Venda region of South Africa. S Afr J Anim Sci. 2015; 45: 143-152.

55. Tadelle D, Million T, Alemu Y, Peters K. Village chicken production systems in Ethiopia: 1. Flock characteristics and performance. Livestock Research for Rural Development, 2003; 15.

56. Rodriguez JC, Segura JC, Alzina A, Gutierrez MA. Factors affecting mortality of crossbred and exotic chickens under backyard systems in Yucatan, Mexico. Trop Anim Hlth Prod. 1997; 29: 151-157.

57. Osman KM, Aly MM, Amin ZM, Hasan BS. Mycoplasma gallisepticum: an emerging challenge to the poultry industry in Egypt. OIE Rev Sci Tech, 2009 28: 1015-1023.

58. Binta MG, Mushi EZ, Adam EK, Diteko T. Diseases of chickens in Botswana. Bull Anim Hith Prod Africa, 1996; 44: 215-218.

59. van Eekeren N, Maas A, Saatkamp HW, Verschuur M. Small-scale poultry production in the tropics. $3^{\text {rd }}$ edn. Wageningen: Agromisa Foundation. 2004

60. Cappelle J, Caron A, Servan De Almeida R, Gil P, Pedrono M, Mundava J, et al. Empirical analysis suggests continuous and homogeneous circulation of Newcastle disease virus in a wide range of wild bird species in Africa. Epidemiol Infect. 2015; 143: 1292-1303.

61. Saidu L. Abdu PA, Umih JU, Abdullah US. Diseases of Nigerian indigenous chickens. Bull Anim HIth Prod Afr, 1994. 42: 19

62. Sulu AG, Abdu PA. A retrospective study on the prevalence and monthly distribution of Newcastle disease in poultry in Baluchi State, Nigeria. Sokoro J Vet Sci. 2018; 16: 102-105.

63. Annapragada A, Borgerson C, lams S, Ravelomanantsoa MA, Crawford GC, Helin M. Modeling the impact of Newcastle Disease Virus vaccinations on chicken production systems in Northeastern Madagascar. Front Vet Sci. 2019; 6: 305.

64. Samuel JL, Bensink Z, Spradbrow PB. Oral vaccination of chickens with the V4 strain of Newcastle disease vaccine. Cooked and raw white rice as vehicle. Trop Anim HIth Prod. 1993; 25: 2-10.

65. Nidup K, Tshering P. Status of the family poultry production and HPAI in Bhutan. Proceedings of the 8th Asian Pacific Poultry Conference: science to solutions, 5-6 March 2007, Bangkok. Bangkok: World's Poultry Science Association Thailand Branch. 2007; 78-83.

66. Echeonwu BC, Ngele MB, Echeonwu GON, Joannis TM, Onovoh EM, Paul G. Response of chickens to oral vaccination with Newcastle disease virus vaccine strain I2 coated on maize offal. Afr J Biotech. 2008; 7: 1594-1599.

67. Henning J, Morton J, Pym R, Hla T, Meers J. Evaluation of strategies to improve village chicken production: controlled field trials to assess effects of Newcastle disease vaccination and altered chick rearing in Myanmar [corrected]. Prev Vet Med, 2009; 90: 17-30.

68. Branckaert RDS. Avian Influenza: The new challenge for family poultry World's Poultry Sci J. 2007; 63: 129-131.

69. Sonaiya EB. Family poultry, food security and the impact of HPAI. World's Poultry Sci J. 2007; 63: 132-138.

70. Serrão E, Meers J, Pym R, Copland R, Eagles D, Henning J. Prevalence and incidence of Newcastle disease and prevalence of Avian Influenza infection of scavenging village chickens in Timor-Leste. Prev Vet Med. 2012; 104 301-308.

71. Molia S, Grosbois V, Kamissoko B, Sidibe MS, Sissoko KD, Traore I, et al. Longitudinal study of Avian Influenza and Newcastle Disease in Village Poultry, Mali, 2009-2011. Avian Dis. 2017; 61: 165-177.

72. Henning J, Henning KA, Morton JM, Long NT, Ha NT, Vu le T, et al. Highly pathogenic avian influenza (H5N1) in ducks and in-contact chickens in backyard and smallholder commercial duck farms in Viet Nam. Prev Vet Med. 2011; 101: 229-240.

73. Henning J, Wibawa H, Morton J, Usman TB, Junaidi A, Meers J. Scavenging ducks and transmission of highly pathogenic avian influenza, Java, Indonesia. Emerg Infect Dis. 2010; 16: 1244-1250.

74. Lubroth J. Control strategies for highly pathogenic avian influenza: a global perspective. Dev Biol (Basel). 2007; 130: 13-21.

75. Alders R, Awuni JA, Bagnol B, Farrell P, de Haan N. Impact of Avian Influenza on village poultry production globally. Eco Health. 2013.

76. Miers H. Poverty, Livelihoods and HPAI-A Review (Mekong Team Working Paper No. 1). London: Department for International Development. 2008.

77. Msoffe PLM, Mtambo MMA, Minga UM, Olsen JE, Juul-Madsen HR Gwakisa PS, et al. Productivity and reproductive performance of the freerange local domestic fowl ecotypes in Tanzania. Livestock Research for Rural Development. 2004; 16.

78. Asiedu FHK, Weever W. Growth rate and egg production of Creole and Rhode Island Red x Creole fowls. Trop Anim HIth Prod. 1993; 25: 111-117.

79. Maphosa T, Kusina J, Kusina NT, Makuza S, Sibanda S. A monitoring study comparing production of village chickens between communal (Nharira) and small-scale commercial (Lancashire) farming areas in Zimbabwe. Livestock Research for Rural Development. 2004; 16

80. Omeje SSI, Nwose CC. Egg production patterns in local chickens and their crosses in the short term. Nigerian J Anim Prod. 1983; 10: 91-96.

81. Magothe TM, Okeno TO, Muhuyi WB, Kahi AH. Indigenous chicken production in Kenya: I. Current status. World's Poultry Sci J. 2012; 68: 119132

82. Mahoro J, Muasya TK, Mbuza F, Habimana R, Kahi AK. Characterization of indigenous chicken production systems in Rwanda, Poultry Sci, 2017; 96: 4245-4252.

83. Saina H, Kusina NT, Kusina JF, Bhebhe E, Lebel S. Guinea fowl production by indigenous farmers in Zimbabwe. Livestock Research for Rural Development. 2005: 17

84. Nwagu B, Alawa C. Guinea fowl production in Nigeria. World's Poultry Sc J. 1995; 51: 261-270.

85. Naandam J, Issah GB. Hatchability of Guinea fowls eggs and performance of keets under the traditional extensive system in Tolon-Kumbungu district of Ghana. Online J Anim Feed Res. 2012; 2: 253-257.

86. Banga-Mboko H, Maes D, Leroy PL. Indigenous Muscovy ducks in CongoBrazzaville. 1. A survey of indigenous Muscovy duck management in households in Dolisie City. Trop Anim Health Prod. 2007; 39: 115-122.

87. Islam MF, Mia MM, Rahman MA, Bhowmik N. Morphometric, productive and reproductive traits of indigenous goose of Bangladesh. Anim Genet Res. 2016; 59: 37-45

88. Wilson RT. The White Meat Value Chain in Tanzania: A Report from the Southern Highlands Food Systems Programme. Rome: Food and Agriculture Organization. 2015.

89. Swai ES, Karimuribo ED, Kyakaisho PF, Mtui PF. Free-range village chickens on the humid coastal belt of Tanga, Tanzania: their roles, husbandry and health status. Livestock Research for Rural Development. 2007; 19.

90. Assefa F, Tadesse T, Dancho A. Challenges and opportunities of village poultry production in Arbegona woreda, Sidama Zone, Southern Ethiopia. Developing Country Studies. 2015; 5: 71-78

91. Guèye E. Employment and income generation through family poultry in lowincome food-deficit countries. World's Poultry Sci J. 2002; 58: 541-557.

92. de Bruyn J, Wong J, Bagnol B, Pengelly B, Alders, R. Family poultry production and food and nutrition security. CAB Reviews, 2015; 10: 1-9.

93. Aning KG. The structure and importance of commercial and village based poultry in Ghana: Final Review |Report, Accra: Food and Agriculture Organization. 2006.

94. Mack S, Hoffman D, Otte J. The contribution of poultry to rural development World's Poultry Sci J. 2005; 61: 7-14.

95. Tomo AA. Economic impact of Newcastle Disease control in village chickens: a case study in Mozambique. M.Sc. Dissertation. Semantic Scholar. 2009; Corpus ID: 72949292

96. Henning J, Morton J, Pym R, Hla T, Sunn K, Meers J. Economic analysis 
of interventions to improve village chicken production in Myanmar. Prev Vet Med, 2013; 110: 525-540.

97. Tadelle D, Alemu Y, Peters K. Indigenous chickens in Ethiopia: Genetic potential and attempts at improvement. World's Poultry Sc J. 2000;. 56: 4554

98. Nidup K, Dorji P, Penjor. A review of poultry development in Bhutan International Network for Family Poultry Development Newsl. 2005; 15: 8-15.

99. Panda B. Role of poultry in socio economic development of small farmers in India. Asian Livestock. 1987; 12: 145-148.
100. Prawirokusumo S. Problems to improve small scale native chicken management in South-east Asian countries. Proceedings of the Eighteenth World's Poultry Congress, 4-9 September 1988, Nagoya, Japan. Tokyo: Japan Poultry Science Association. 1988. 113-115.

101. Cresswell DC, Gunawan B. Indigenous chickens in Indonesia. Production characteristics in an improved environment (Report No. 2). Bogor, Indonesia: Research Institute for Animal Production. 1982; 9-14. 